\title{
Functional health literacy in hypertensive elders at primary health care
}

\author{
Alfabetismo funcional em saúde em pessoas idosas hipertensas na atenção primária \\ Alfabetismo funcional en salud en personas hipertensas en la atención primaria
}

\section{Victor Roberto Santos Costa' ORCID: 0000-0002-0785-9665 \\ Polyana D'arc Rezende Costa' ORCID: 0000-0003-4269-5448}

Eduardo Yoshio Nakano" ORCID: 0000-0002-9071-8512

Daniel Apolinário"II ORCID: 0000-0002-0261-129X

Alfredo Nicodemos Cruz Santana'

ORCID: 0000-0002-4511-9123

'Escola Superior de Ciências da Saúde. Brasília, Distrito Federal, Brazil.

"Universidade de Brasília. Brasília, Distrito Federal, Brazil. III Universidade de São Paulo. São Paulo, São Paulo, Brazil.

How to cite this article:

Costa VRS, Costa PDR, Nakano EY, Apolinário D, Santana ANC. Functional health literacy in hypertensive elders at primary health care. Rev Bras Enferm. 2019;72(Suppl 2):266-73. doi: http://dx.doi.org/10.1590/0034-7167-2018-0897

Corresponding Author:

Alfredo Nicodemos Cruz Santana E-mail alfredoncs@gmail.com

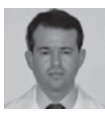

Submission: 01-29-2019 Approval: 06-09-2019

\section{ABSTRACT}

Objective: to assess the relationship between inadequate functional health literacy and inadequate blood pressure control in older people with hypertension in Primary Health Care. Method: a cross-sectional study with sample calculated at 392. SAHLPA-18 tool was used for functional health literacy; blood pressure was measured; sociodemographic and clinical data were collected. Hierarchical logistic regression was used. Results: (high) inadequate blood pressure and (low) functional inadequate health literacy were present in $41.6 \%$ and $54.6 \%$ of the people, respectively. Factors associated with inadequate blood pressure were: inadequate functional health literacy, blackbrown skin color, overweight-obesity, hypertension diagnosis time, non-adherence to exercise/diet, drug treatment. Schooling had no association with inadequate blood pressure Conclusion: hypertensive elderly people with inadequate health literacy were more likely to have inadequate blood pressure. Thus, health professionals need to value functional health literacy as a possible component to control blood pressure. Descriptors: Health Literacy; Aged; Primary Health Care; Health Vulnerability.

\section{RESUMO}

Objetivo: avaliar a relação entre alfabetismo funcional em saúde inadequado e controle inadequado da pressão arterial em pessoas idosas hipertensas na Atenção Primária. Método: estudo transversal com amostra calculada em 392. Foi usado instrumento SAHLPA-18 para alfabetismo funcional em saúde; aferida a pressão arterial; coletados dados sociodemográficos e clínicos. Utilizou-se regressão logística hierárquica. Resultados: pressão arterial inadequada(alta) e alfabetismo funcional em saúde inadequado(baixo) estavam presentes em $41,6 \%$ e $54,6 \%$ das pessoas, respectivamente. Fatores associados com pressão arterial inadequada foram: alfabetismo funcional em saúde inadequado, cor parda-negra, sobrepeso-obesidade, tempo de diagnóstico da hipertensão, não adesão a exercício/dieta, não adesão a tratamento medicamentoso. O nível de escolaridade não teve associação com pressão arterial inadequada. Conclusão: pessoas idosas hipertensas com alfabetismo funcional em saúde inadequado apresentaram mais chance de ter pressão arterial inadequada. Assim, profissionais de saúde precisam valorizar o alfabetismo funcional em saúde como possível componente para controlar a pressão arterial.

Descritores: Alfabetização em Saúde; Idoso; Hipertensão; Atenção Primária à Saúde; Vulnerabilidade em Saúde.

\section{RESUMEN}

Objetivo: evaluar la relación entre alfabetismo funcional en salud inadecuada y control inadecuado de la presión arterial en personas ancianas hipertensas em la Atención Primaria de Salud. Método: estudio transversal com muestra calculada en 392. Se utilizó instrumento SAHLPA-18 para alfabetismo funcional en salud; a la presión arterial; recogidos datos sociodemográficos y clínicos. Se utilizo La regresión logística jerárquica. Resultados: La presión arterial inadecuada (alta) y el alfabetismo funcional en salud inadecuada (bajo) estaban presentes en el $41,6 \%$ y el $54,6 \%$ de las personas, respectivamente. Los factores asociados com la presión arterial inadecuada fueron: alfabetismo funcional en salud inadecuada, color parda-negra, sobrepeso-obesidad, tiempo de diagnóstico de la hipertensión, no adhesión a ejercicio/dieta, no adhesión al tratamiento medicamentoso. El nivel de escolaridad no tuvo asociación con la presión arterial inadecuada. Conclusión: las personas mayores hipertensas con alfabetismo funcional em salud inadecuada presentaron más posibilidades de tener presión arterial inadecuada. Así, los profesionales de La salud necesitan valorizar el alfabetismo funcional en salud como posible componente para controlar la presión arterial.

Descriptores: Alfabetización en Salud; Ancianos; Hipertensión; Atención Primaria de Salud; Vulnerabilidad en Salud. 


\section{INTRODUCTION}

Over the past few years, studies have shown that chronic diseases control is not adequately predicted by formal schooling alone. Thus, a broader construct called functional health literacy emerged ${ }^{(1-2)}$. Functional health literacy represents the ability to interpret texts and numbers that are usually present in test results or prescriptions, as well as in guidance leaflets ${ }^{(1-4)}$. In this way, some tests were developed to measure functional health literacy ${ }^{(2-6)}$. Thus, the level of functional health literacy can be classified as adequate or inadequate ${ }^{(4)}$.

Regarding the international setting related to functional health literacy, it is worth mentioning that this literacy is known to be important in several aspects of health promotion and diseases treatment. Thus, functional inadequate health literacy is associated with a lower level of physical activity, lower fruit and vegetable consumption, poor adherence to drug treatment, poorer chronic diseases control, worse postoperative evolution, higher health care costs, and higher mortality, including in the elderly ${ }^{(7-10)}$.

Specifically on functional health literacy and Systemic Arterial Hypertension control in the international setting, some points deserve to be highlighted: patients with functional inadequate health literacy have worse adherence to drug treatment; worse hypertension control; worse quality of life; and increased risk of strokes $^{(11-14)}$. Thus, increasing the level of functional health literacy is part of the objectives of monitoring hypertensive patients ${ }^{(12)}$.

Assessing with specific focus on hypertensive elderly and functional health literacy, there are few international studies, especially, involving population with low schooling. The Brazilian elderly population also has this profile of low schooling, and therefore, to analyze this kind of study well is fundamental. This research shows that functional health literacy plays a role in the pressure levels of hypertensive elderly people treated in primary care, and suggests that functional health literacy is a guideline of the Ministry of Health's public policies ${ }^{(13)}$.

In relation to the Brazilian overview of functional health literacy, studies on this subject have only recently been published by national researchers more frequently ${ }^{(15-21)}$. In these articles, adequate functional health literacy may allow a prospective learning facilitator to play a role in the caring process of cardiac pacemaker patients ${ }^{(15)}$. However, in people living with HIV, functional health literacy can influence educational technologies, and adherence to antiretroviral treatment ${ }^{(16)}$.

In Brazil, there are specific studies on diabetes and chronic kidney disease. In diabetic patients, functional inadequate health literacy can impair the self-care process ${ }^{(18)}$. Finally, in patients with chronic kidney disease, it is urgent to improve functional literacy in the health of such patients. The use of a primer based on functional health literacy can help health professionals communicate better with such sick people, possibly by optimizing therapeutic outcomes ${ }^{(17,19)}$.

Although functional health literacy is an important topic for the understanding of the factors that influence blood pressure control of hypertensive elderly people, this type of study is unknown in Brazil. It is worth remembering that there are authors who defend that functional health literacy is part of the Ministry of Health's public policy and is routinely addressed in Primary Health Care (PHC), especially when related to elderly people ${ }^{(13,22)}$.

\section{OBJECTIVE}

To ascertain whether functional inadequate health literacy would be independently associated with inadequate blood pressure control in elderly hypertensive patients treated at PHC.

\section{METHOD}

\section{Ethical aspects}

The study was approved by the Research Ethics Committee of our institution, and was developed in compliance with Resolution $466 / 2012$ of the Brazilian National Health Board (Conselho Nacional de Saúde). Hypertensive elderly people were invited to participate in the study, and those who accepted to participate in the study, after due clarification, signed the Free and Informed Consent Term.

\section{Design, period and place of study}

It is a cross-sectional, observational, quantitative and analytical study, guided by STROBE. It was developed in a city of the southern region of the Federal District from June to December 2017.

\section{Sample; inclusion and exclusion criteria}

Hypertensive elderly individuals were approached in primary health care units of Gama by 2 interviewers previously trained. Such elderly people were expecting some type of care, such as consultation with a health professional, dressing, educational activity, etc., in the primary care unit, similar to an important study done in primary care units by Silva et al. ${ }^{(23)}$.

The inclusion criteria for participating in the study were being 60 years or older, being accompanied by hypertension in the primary care units of Gama, and using at least one medication for hypertension daily for at least a year ${ }^{(24)}$. Patients were excluded who declared that they always or almost always need help to organize and to remember to take the medications, that they were not able to respond adequately to the questionnaires due to problem of severe uncorrected deafness, vision, motor or language, cognitive impairment by the test cognitive impairment 10-CD (score $\leq 5$ ), diagnosis of dementia, delirium, psychotic or substance-related mental disorders according to the criteria of DSM-5 and foreigners that do not know Portuguese.

In order to delimit the sample size of the study, this sample calculation aimed at this study to be capable of detecting even the magnitude difference of 'Cohen d' effect equal to 0.3. Moreover, it was expected that this study had $80 \%$ power, and an alternative bilateral hypothesis and an alpha error of 0.05 . Thus, an initial value of 356 was obtained. However, $10 \%$ were added due to possible losses, reaching the final number of 392 individuals. As for the number of elderly hypertensive patients included in the study in each primary care unit, this was calculated as recommended in the scientific literature and as follows: $392 \times$ (elderly population under the responsibility of the primary care unit/elderly population of the city of Gama) ${ }^{(23)}$.

\section{Study protocol}

For data collection, the interviews with the hypertensive elderly were performed by 2 previously trained researchers. These interviews 
occurred in the morning or afternoon shifts, according to availability of each researcher, being in agreement with Silva et al ${ }^{(23)}$. Such elderly people were waiting for some type of care, such as consultation with health professionals, dressing, educational activity, etc., in the primary health care unit ${ }^{(23)}$. A structured questionnaire was used during the interviews, aiming to collect sociodemographic and clinical data. Data were selected based on previous studies with elderly people, such as SABE (Health, Welfare and Aging) $)^{(25-27)}$.

As the frames of cognitive impairment are largely underdiagnosed in clinical practice, the 10-point cognitive assessment test, called 10-CS, was applied. This tool was validated in Brazil and assesses temporal orientation, verbal fluency and episodic memory ${ }^{(28)}$. 10-CS has characteristics that make it particularly advantageous for use in clinical practice, such as rapid application, not requiring specific materials for its application, suitable for elderly or low education populations. Elderly subjects with a score $\leq 5$ in 10-CS, indicating probable cognitive impairment, were excluded from the study ${ }^{(28)}$.

Socio-demographic data had information regarding age in years, gender, skin color, educational level - years of schooling, economic class - as measured by the Brazilian Economic Classification Criteria (CCEB - Critério de Classificação Econômica Brasil) version 2015, and marital status. Clinical data had information on the time of diagnosis of systemic arterial hypertension, number of visits per year, overweight and obesity, life habits, such as physical activity and diet, depression, health vulnerability, adherence to drug therapy, knowledge about hypertension, difficulty receiving medication.

Blood pressure measurements were followed by standardized instructions. Measurements of the brand Omron Healthcare model HEM-7113 (HEM-7051 E equivalent), validated by the European Society of Hypertension, and recommended by the Brazilian Society ${ }^{(29-30)}$. The American Academy of Family Physicians (AAFP) and the American College of Medicine (ACP) established in their latest guideline that, after blood pressure measurement, elderly hypertensive patients should be classified into two groups: patients with inadequate control (systolic blood pressure (SBP) $\geq 150 \mathrm{mmHg}$ OR diastolic blood pressure (DBP) $\geq 90 \mathrm{mmHg}$ ) and patients with adequate control (SBP $<150 \mathrm{mmHg}$ AND DBP $<90 \mathrm{mmHg})^{(31)}$.

To assess functional health literacy, the Brazilian 18-item Short Assessment of Health Literacy for Portuguese-Speaking Adults; SAHLPA-18 was used. It tests the pronunciation and understanding of medical terms commonly used in health care settings. The tool was previously validated in a sample of Brazilian elderly ${ }^{(4)}$.

For the application of SAHLPA-18, cards containing the medical key term in bold on the top of the card (e.g., osteoporosis) and two words on the bottom of the card are used: one of correct association (e.g., bone) and one that serves as a distractor (e.g., muscle).Initially, the patient reads the key word out loud and then the interviewer reads the other two words. The patient should then say which one is associated with the keyword. The item is only considered correct when the patient hits the pronunciation and association. Each correct item receives a point, and the total score is obtained by the simple sum, ranging from 0 to 18 . Total score from 0 to 14 would be classified as inadequate functional health literacy ${ }^{(4)}$.

In order to assess the adherence to drug therapy of Systemic Arterial Hypertension by the patients, the MAT validity scale was used $^{(32)}$. This tool has previously been used in Brazil to assess the adherence to drug treatment in individuals with hypertension or with diabetes ${ }^{(24)}$. The questionnaire contains 7 questions, whose answers are: always ( 1 point); almost always ( 2 points); frequently (3 points); sometimes (4 points); rarely (5 points); or never (6 points). After obtaining the answers of each MAT item, add the points and divide by the total number of questions. Patients are divided dichotomically into adherents and non-adherents, with adherents with scores 5 or more ${ }^{(24,32)}$.

Knowledge regarding systemic arterial hypertension was assessed by means of a previously validated questionnaire that uses 10 questions with yes or no answers, one point being assigned to each true response ${ }^{(33)}$. To be considered as satisfactory knowledge of the disease, the patient should at least 7 of the 10 questions applied $^{(33)}$.

The Vulnerable Elders Survey (VES-13) was used to characterize the level of health vulnerability in the elderly sample of this study. It consists of 13 items that include: age, self-reported health, functional capacity and physical condition ${ }^{(34)}$. After obtaining the answers, patients are classified as: non-vulnerable if they score $<3$ or if they score $\geq 3$ points ${ }^{(34-35)}$.

\section{Analysis of results, and statistics}

Data were analyzed with Stata version 8 SE. The normality of the interval variables - age, schooling, time of diagnosis, number of consultation - was assessed with the Shapiro-Wilk test. As none of the cited variables had a normal distribution, nonparametric tests were used. The Wilcoxon Rank-Sum test, also known as Mann-Whitney, was used to compare the interval variables between the two groups - adequate control versus inadequate blood pressure control. For comparison of categorical variables between the two groups-adequate control versus inadequate blood pressure control, the Chi-Square test was used. Finally, a logistic regression model was used in hierarchical strategy with inadequate blood pressure control as a dependent variable, inadequate health literacy (SAHLPA-18 $\leq 14$ ) as the primary independent variable. In the first stage of the regression, adjustment was made for sociodemographic data; already in the second stage, also adjusted for potentially relevant clinical data. The pseudo coefficient of determination $\left(R^{2}\right)$ indicates the proportion of the variance that can be explained by the model. Statistical significance was considered present when $p$ value reached 0.05 .

\section{RESULTS}

A total of 596 patients were considered for possible inclusion in the study. However, 71 did not agree to participate in the study, 46 were excluded because they had cognitive impairment detected by 10-CS, and 87 because they reported that they always or almost always needed help in organizing and remembering to take their medications. Thus, 392 patients were included in the study, satisfying the sample calculation previously described. The main clinical and sociodemographic characteristics of all hypertensive elderly people $(\mathrm{N}=392)$ included in the study are presented below. 
Blood pressure was not controlled in $41.6 \%$ of the individuals, and inadequate functional health literacy was present in $54.6 \%$. In relation to age, this was 68.83 years ( \pm 5.81 years), and $36.7 \%$ were male. For the color variable, $48.2 \%$ declare brown or black. The mean educational level was 5.78 years ( \pm 2.96 years). As for economic class, $47.7 \%$ belonged to class $C$ or D or E. Status without spouse or partner was present in $39.5 \%$ of the sample. In addition, depression was present in $17.1 \%$, overweight-obesity in $58.7 \%$, and Vulnerable Elders Survey (VES-13) in 43.9\%.

Regarding aspects directly related to hypertension in all subjects included in this study ( $\mathrm{N}=392)$, the following data were obtained: the mean time of diagnosis of hypertension was 11.91 years ( \pm 8.87 years); $16.3 \%$ did not diet or exercise; $29.3 \%$ considered it difficult/very difficult to purchase drugs; had a mean number of visits per year of $2.12( \pm 1.17)$; and, $37.0 \%$ had non-adherence to drug treatment (MAT).

In Table 1, data are compared between elderly hypertensive patients with adequate blood pressure control ('adequate blood pressure control', $\mathrm{N}=229$ ) and those with inadequate blood pressure control ('inadequate blood pressure control group'; $N=163$ ). In the inadequate blood pressure control group ( $\mathrm{N}=163)$, the following variables are observed, with significant statistical difference.

The prevalence of inadequate functional health literacy was higher (69.3\%). The males were more present (42.9\%). Regarding color, self-statement of browns/blacks (60.1\%) prevailed. Schooling was lower (5.36 \pm 3.00 years). In relation to hypertension, they had a longer diagnosis time (13.89 \pm 9.58 years), as well as more visits per year $(2.32 \pm 1.17)$.

The inadequate control group of blood pressure presented the following characteristics with statistical significance.

Overweight-obesity was more prevalent (73.0\%). Regarding non-adherence or partial adherence, exercise and diet, had a higher prevalence (84.2\%). Depression was also more detected (27.0\%), and they were more vulnerable in health (58.3\%). Moreover, more individuals (54.6\%) were classified as non-adherence to medications. Knowledge about hypertension was more frequently classified as insufficient (14.7\%). Finally, the difficulty of obtaining medication was higher and present in $37.4 \%$.

In Table 2, Model 3 represents the final model of multivariate statistical analysis. In this Model 3, the variables independently associated with inadequate blood pressure control in elderly hypertensive individuals were those that follow.

Inadequate functional heath literacy had odds ratio (OR) of 2.07. On the other hand, the black-brown color presented OR of 2.05; and the time of diagnosis of hypertension, OR of 1.04. As for overweight-obesity, this had OR of 1.97. Partial adhesion or non-adherence to exercise and diet was also associated with inadequate blood pressure control (OR of 2.32 and 3.47, respectively). Finally, non-adherence to medication presented OR of 2.66. Thus, the OR of inadequate health functional literacy had a higher value than OR of variables classically related to inadequate blood pressure control, such as overweight-obesity and brown-black.

Table 1 - Sociodemographic and clinical characterization of elderly hypertensive patients with adequate or inadequate blood pressure control, Gama, Distrito Federal, Brazil, 2017

\begin{tabular}{|c|c|c|c|c|}
\hline \multicolumn{2}{|l|}{ Variables } & $\begin{array}{l}\text { Adequate BP Control } \\
(n=229)\end{array}$ & $\begin{array}{l}\text { Inadequate BP Control } \\
\qquad(n=163)\end{array}$ & $p$ value \\
\hline \multicolumn{2}{|c|}{ Inadequate functional health literacy - $\mathrm{n}(\%)$} & $101(44.1)$ & $113(69.3)$ & $<0.001^{1 *}$ \\
\hline \multicolumn{2}{|l|}{ Age in years - mean (SD) } & $68.64(6.08)$ & $69.09(5.43)$ & $0.317^{2}$ \\
\hline \multicolumn{2}{|l|}{ Male - n (\%) } & $74(32.3)$ & $70(42.9)$ & $0.031^{1 *}$ \\
\hline \multicolumn{2}{|l|}{ Brown or black color - $\mathrm{n}(\%)$} & $91(39.7)$ & $98(60.1)$ & $<0.001^{1 *}$ \\
\hline \multicolumn{2}{|c|}{ Schooling in years - mean (SD) } & $6.08(2.92)$ & $5.36(3.00)$ & $0.004^{2 *}$ \\
\hline \multirow[t]{3}{*}{ Economy class - $\mathrm{n}(\%)$} & $A$ and $B$ & $130(56.8)$ & $75(46.0)$ & \\
\hline & $\mathrm{C}$ & $96(41.9)$ & $84(51.5)$ & $0.094^{1}$ \\
\hline & $\mathrm{D}$ and $\mathrm{E}$ & $3(1.3)$ & $4(2.5)$ & \\
\hline \multicolumn{2}{|l|}{ No spouse or partner- $\mathrm{n}(\%)$} & $82(35.8)$ & $73(44.8)$ & $0.073^{1}$ \\
\hline \multicolumn{2}{|c|}{ Time of diagnosis of SAH in years (SD) } & $10.50(8.07)$ & $13.89(9.58)$ & $<0.001^{2 *}$ \\
\hline \multicolumn{2}{|c|}{ Medical consultations per year (SD) } & $1.98(1.15)$ & $2.32(1.17)$ & $0.006^{2 *}$ \\
\hline \multicolumn{2}{|c|}{ Overweight or obesity- $\mathrm{n}(\%)$} & $111(48.5)$ & $119(73.0)$ & $<0.0011^{1 *}$ \\
\hline \multirow[t]{3}{*}{ Exercise and diet- $\mathrm{n}(\%)$} & Total adhesion & $109(47.6)$ & $24(14.7)$ & \\
\hline & Partial adhesion & $94(41.0)$ & $101(61.0)$ & $<0.001^{1 *}$ \\
\hline & Non-adhesion & $26(11.4)$ & $38(23.2)$ & \\
\hline \multicolumn{2}{|l|}{ Depression - n (\%) } & $23(10.0)$ & $44(27.0)$ & $<0.001^{1 *}$ \\
\hline \multicolumn{2}{|c|}{ Health vulnerability(VES-13) - n (\%) } & $77(36.6)$ & $95(58.3)$ & $<0.001^{1 *}$ \\
\hline \multicolumn{2}{|c|}{ Non-adhesion to medication(MAT) - $\mathrm{n}(\%)$} & $56(24.5)$ & $89(54.6)$ & $<0.001^{1 *}$ \\
\hline \multicolumn{2}{|c|}{ Insufficient knowledge about SAH - n (\%) } & $16(7.0)$ & $24(14.7)$ & $0.013^{1 *}$ \\
\hline \multirow[t]{3}{*}{ Receive medication- $\mathrm{n}(\%)$} & Easy & $175(76.4)$ & $102(62.6)$ & \multirow{3}{*}{$0.008^{1 *}$} \\
\hline & Hard & $51(22.3)$ & $55(33.7)$ & \\
\hline & Very hard & $3(1.31)$ & $6(3.7)$ & \\
\hline
\end{tabular}

Note: BP (blood pressure); $n$ (absolute number); \% (number in percent); SD (Standard Deviation); VES-13 (Vulnerable Elders Survey); MAT (Measure of Adhesion to Treatments); SAH (systemic arterial hypertension); 1 (Chi-Square Test); 2 (Wilcoxon Rank-Sum Test); *(Data with statistical significance - $p<0.05)$. 
Table 2 - Logistic regression analysis in hierarchical strategy of the sample of hypertensive elderly people with inadequate blood pressure control as dependent variable, and inadequate functional health literacy as primary independent variable, Gama, Distrito Federal, Brazil, 2017 ( $N=392$ )

\begin{tabular}{|c|c|c|c|c|}
\hline \multirow{2}{*}{ Variables } & & \multicolumn{3}{|c|}{ Odds Ratio (95\% Cl) } \\
\hline & & Model 1 & Model 2 & Model 3 \\
\hline \multicolumn{2}{|c|}{ Inadequate functional health literacy } & $2.86(1.88-4.37)^{* * *}$ & $2.85(1.79-4.55)^{* * *}$ & $2.07(1.20-3.58)^{* *}$ \\
\hline \multicolumn{2}{|l|}{ Age in years } & & $1.01(0.97-1.06)$ & $0.99(0.94-1.04)$ \\
\hline \multicolumn{2}{|l|}{ Male } & & $1.29(0.81-2.04)$ & $1.04(0.60-1.79)$ \\
\hline \multicolumn{2}{|l|}{ Brown or black color } & & $2.24(1.38-3.62)^{* *}$ & $2.05(1.16-3.62)^{*}$ \\
\hline \multicolumn{2}{|l|}{ Schooling in years } & & $1.06(0.96-1.17)$ & $1.11(0.99-1.25)$ \\
\hline \multirow[t]{3}{*}{ Economy class } & $\mathrm{A} / \mathrm{B}$ & & 1 (reference) & 1 (reference) \\
\hline & C & & $1.08(0.67-1.73)$ & $0.75(0.43-1.33)$ \\
\hline & $\mathrm{D} / \mathrm{E}$ & & $1.02(0.23-4.42)$ & $1.25(0.12-13.3)$ \\
\hline \multicolumn{2}{|l|}{ No spouse or partner } & & $1.28(0.80-2.05)$ & $0.97(0.57-1.64)$ \\
\hline \multicolumn{2}{|c|}{ Time of diagnosis of SAH in years } & & & $1.04(1.01-1.08)^{*}$ \\
\hline \multicolumn{2}{|c|}{ Medical consultations per year } & & & $1.08(0.86-1.36)$ \\
\hline \multicolumn{2}{|l|}{ Overweight or obesity } & & & $1.97(1.16-3.33)^{*}$ \\
\hline \multirow[t]{3}{*}{ Exercise and diet } & Total adhesion & & & 1 (reference) \\
\hline & Partial adhesion & & & $2.32(1.23-4.38)^{*}$ \\
\hline & Non-adhesion & & & $3.47(1.51-7.99)^{* *}$ \\
\hline \multicolumn{2}{|l|}{ Depression } & & & $0.70(0.35-1.42)$ \\
\hline \multicolumn{2}{|c|}{ Health vulnerability(VES-13) } & & & $1.70(0.94-3.08)$ \\
\hline \multicolumn{2}{|c|}{ Non-adherence to medications (MAT) } & & & $2.66(1.50-4.72)^{* *}$ \\
\hline \multicolumn{2}{|c|}{ Insufficient knowledge about SAH } & & & $0.58(0.25-1.35)$ \\
\hline \multirow[t]{3}{*}{ Receiving Medication } & Easy & & & 1 (reference) \\
\hline & Hard & & & $0.98(0.55-1.77)$ \\
\hline & Very hard & & & $2.87(0.40-20.6)$ \\
\hline
\end{tabular}

Note: ${ }^{*}(p<0.05) ;{ }^{* *}(p<0.01) ;{ }^{* * *}(p<0.001) ;$ SAH (systemic arterial hypertension); VES-13 (Vulnerable Elders Survey); MAT (Measure of Adhesion to Treatments).

\section{DISCUSSION}

To the best of our knowledge, this study was the first in Brazil to show that functional inadequate health literacy is associated with inadequate blood pressure control in elderly hypertensive patients treated at PHC. In addition, there are few studies on this specific topic in the international literature justifying further studies ${ }^{(13-14)}$. With the data presented in this article, we can suggest a greater attention by primary health care teams in caring for hypertensive elderly people with inadequate health functional literacy, since such individuals are more likely to have inadequate blood pressure control.

In relation to the previous studies of functional health literacy in hypertensive elderly people, some points stand out ${ }^{(13-14)}$.

In the study by Wannasirikul P et al in Thailand, the elderly had the same level of functional inadequate health literacy compared to the present study ${ }^{(13)}$. Moreover, in the Wannasirikul $P$ et al study, the greatest effect on blood pressure level was functional health literacy ${ }^{(13)}$. In the study by McNaughton et al in the United States of America, inadequate functional health literacy was present in $23 \%$ of the individuals, and the high blood pressure level was more prevalent in those with inadequate health literacy than those with adequate literacy (40.0\% versus $35.5 \%$, adjusted Odds Ratio 1.06 (95\% Cl: 1.01-1.12) ${ }^{(14)}$. Thus, in settings with different prevalence of inadequate functional health literacy and in countries with different socioeconomic and cultural profiles, functional health literacy showed association with blood pressure control, corroborating the findings of the present study.

Inadequate functional health literacy is associated with poorer and costlier health care. Even so, most health professionals cannot identify this problem and are not prepared to deal with patients with inadequate health literacy ${ }^{(36)}$. Moreover, functional inadequate health literacy is a public health problem even in countries with an excellent educational and socioeconomic level, such as Canada(37).

Unexpectedly, schooling, measured in years, had no association, in the multivariate analysis, with blood pressure control in the present study. However, this reinforces that the most important is to assess functional health literacy, not only schooling, since it is related to obtaining, understanding and using information in order to promote their own health ${ }^{(4)}$. Moreover, another problem in Brazil is that, although they have some degree of schooling, measured in years, many individuals cannot read, write or do mathematical accounts in order to solve their everyday demands ${ }^{(38)}$.

In this study, having brown or black color was associated with inadequate blood pressure control. This is widely known and discussed in the literature, because systemic arterial hypertension is more severe among people of the dark or black color, besides the socioeconomic and environmental factors involved that aggravate this picture ${ }^{(39)}$. In addition, not dieting or exercise, or being overweight-obesity, were independently associated with inadequate blood pressure control in the present study, being in agreement with literature ${ }^{(39)}$. However, it is essential to remind health professionals that hypertension control 
is not restricted to prescribing antihypertensive agents, and that it is fundamental to act on the behavioral aspects, life style, related to such clinical condition ${ }^{(39)}$.

Regarding non-adherence to the drug treatment assessed by MAT, it was also associated with the inadequate blood pressure control in the present study. It is worth emphasizing that 37\% (145/392) of patients presented non-adherence to the drug treatment, being an important space for action of the PHC teams. In another study performed with hypertensive elderly people in the city of Uberaba, a significant percentage of respondents did not adhere to treatment correctly ${ }^{(40)}$. Moreover, non-adherence therapy not only impairs proper blood pressure control but also promotes the development of heart failure, coronary artery disease, renal failure and stroke ${ }^{(41)}$.

Another important point is to see if the results of the present study replicate in other settings of $\mathrm{PHC}$ in different Brazilian cities - external validation question. Thus, more studies in Brazil are necessary with this theme, considering that this research is the first, as far as the authors know. However, it is believed that these results, presented here, will be replicated, since the sample of hypertensive elderly people of the present study is similar to that of other studies, especially as a predominance of females, the majority with schooling around 4 to 7 years, and mean time to diagnosis of hypertension greater than 10 years $^{(40)}$.

\section{Study limitations}

This study has some limitations. First, the cross-sectional study characterizes intrinsic limitations, especially related to not establishing a causal relationship, but rather an association between functional health literacy and blood pressure control. However, the cross-sectional study is widely used in the literature for association studies, including functional health literacy studies ${ }^{(13,42-43)}$.Second, the functional health literacy measurement tool used in this study, although validated for use in the Brazilian population, does not include tasks involving numerical, interactive and critical skills that are very important for functional health literacy. However, this limitation is present in other studies in this area of functional health literacy $y^{(42,44)}$. Therefore, the aforementioned limitations do not invalidate the results found in this study, especially related to the importance of the topic addressed, reinforcing the need to value functional health literacy in hypertensive elderly people assisted at PHC.

\section{Contributions to Nursing, Health or Public Policy}

Knowing that functional health literacy is associated with blood pressure control in hypertensive elderly people treated in $\mathrm{PHC}$ will contribute to a more adequate professional practice, especially benefiting patients with more difficulty understanding drug and non-drug prescriptions, and the results of exams.

\section{CONCLUSION}

The findings indicated a high prevalence of inadequate functional health literacy and inadequate blood pressure control among hypertensive elderly people treated at PHC.

Moreover, inadequate functional health literacy, black-brown colored, greater time to diagnose systemic hypertension, overweight-obesity, non-adherence or partial adherence to exercise and diet, and non-adherence to medications were associated with statistical significance and inadequate blood pressure control.

Finally, it seems relevant to suggest the implementation of strategies that improve functional health literacy in hypertensive elderly people. Additionally, it seems adequate to instruct and educate health professionals to use functional health literacy to personalize care, meeting the needs of these elderly people. Thus, it is important to carry out other studies addressing this topic to deepen the knowledge about this clinical situation, which is of great importance for public health.

\section{FUNDING}

This research received funding through the scientific initiation scholarship grant CNPq (Brazilian National Council for Scientific and Technological Development -Conselho Nacional de Desenvolvimento Científico e Tecnológico) - FEPECS-ESCS 2017-2018, being part of the master's thesis of the author Victor Roberto Santos Costa.

\section{REFERENCES}

1. Nutbeam D. Health promotion glossary. Health Promot Int. 1998;13(4):349-64. doi: 10.1093/heapro/13.4.349

2. Santos MIPO, Portella MR, Scortegagna HM, Santos PCS. Functional health literacy from the perspective of gerontological nursing: an integrative literature review. Rev Bras Geriatr Gerontol. 2015;18(3):651-64. doi: 10.1590/1809-9823.2015.14080

3. Van den Broucke S. Health literacy: a critical concept for public health. Arch Public Health. 2014;72:10. doi: 10.1186/2049-3258-72-10

4. Apolinario D, Braga RCOP, Magaldi RM, Busse AL, Campora F, Brucki S, et al. Short Assessment of Health Literacy for Portuguese-Speaking Adults. Rev Saúde Pública. 2012;46(4):702-11. doi: 10.1590/S0034-89102012005000047

5. Quemelo PRV, Milani D, Bento VF, Vieira ER, Zaia JE. Literacia em saúde: tradução e validação de instrumento para pesquisa em promoção da saúde no Brasil. Cad Saúde Pública. 2017;33(2):e00179715. doi: 10.1590/0102-311x00179715

6. Maragno CAD, Mengue SS, Moraes CG, Rebelo MVD, Guimarães AMM, Dal Pizzol TDS. Test of health literacy for Portuguese-speaking adults. Rev Bras Epidemiol. 2019;22:e190025. doi: 10.1590/1980-549720190025

7. Lin SC, Chen IJ, Yu WR, Lee SD, Tsai TI. Effect of a community-based participatory health literacy program on health behaviors and health empowerment among community-dwelling older adults: a quasi-experimental study. Geriatr Nurs. 2019;pii:S0197-4572(18)30397-5. doi: 10.1016/j.gerinurse.2019.03.013 
8. Liu YB, Xue LL, Xue HP, Hou P. Health Literacy, Physical and mental health, and activities of daily living among older Chinese adults in nursing homes. Asia Pac J Public Health. 2018;30(6):592-9. doi: 10.1177/1010539518800368

9. Fawns-Ritchie C, Starr JM, Deary IJ. Role of cognitive ability in the association between functional health literacy and mortality in the Lothian Birth Cohort 1936: a prospective cohort study. BMJ Open. 2018;8(9):e022502. doi: 10.1136/bmjopen-2018-022502

10. Bostock S, Steptoe A. Association between low functional health literacy and mortality in older adults: longitudinal cohort study. BMJ. 2012;344:e1602. doi: 10.1136/bmj.e1602

11. Lor M, Koleck TA, Bakken S, Yoon S, Dunn Navarra AM. Association between health literacy and medication adherence among Hispanics with hypertension. J Racial Ethn Health Disparities. 2019;6(3):517-24. doi: 10.1007/s40615-018-00550-z

12. Shi D, Li J, Wang Y, Wang S, Liu K, Shi R, et al. Association between health literacy and hypertension management in a Chinese community: a retrospective cohort study. Intern Emerg Med. 2017;12(6):765-76. doi: 10.1007/s11739-017-1651-7

13. Wannasirikul P, Termsirikulchai L, Sujirarat D, Benjakul S, Tanasugarn C. Health Literacy, Medication Adherence, and Blood Pressure Level among Hypertensive Older Adults Treated at Primary Health Care Centers. Southeast Asian J Trop Med Public Health [Internet]. 2016 [cited 2019 Apr 15];47(1):109-20. Available from: https://pdfs.semanticscholar.org/28f7/48b009a7cbc21c15dfd29e71865b3f17f138.pdf

14. McNaughton CD, Kripalani S, Cawthon C, Mion LC, Wallston KA, Roumie CL. Association of health literacy with elevated blood pressure: a cohort study of hospitalized patients. Med Care. 2014;52(4):346-53. doi: 10.1097/MLR.0000000000000101

15. Santos JEM, Brasil VV, Moraes KL, Cordeiro JABL, Oliveira GF, Bernardes CP, et al. Comprehension of the education handout and health literacy of pacemaker users. Rev Bras Enferm [Internet]. 2017;70(3):633-9. doi: 10.1590/0034-7167-2016-0336

16. Cunha GH, Galvão MT, Pinheiro PNC, Vieira NFC. Health literacy for people living with HIV/Aids: an integrative review. Rev Bras Enferm [Internet]. 2017;70(1):169-77. doi: 10.1590/0034-7167-2015-0052

17. Moraes KL, Brasil VV, Oliveira GF, Cordeiro JABL, Silva AMTC, Boaventura RP, et al. Functional health literacy and knowledge of renal patients on pre-dialytic treatment. Rev Bras Enferm [Internet]. 2017;70(1):147-53 doi: 10.1590/0034-7167-2015-0169

18. Santos MIPO, Portella MR. Conditions of functional health literacy of an elderly diabetics group. Rev Bras Enferm [Internet]. 2016;69(1):14452. doi: 10.1590/0034-7167.2016690121i

19. Santos LTM, Bastos MG. Developing educational material on chronic kidney disease using best practices in health literacy. J Bras Nefrol. 2017;39(1):55-8. doi: 10.5935/0101-2800.20170009

20. Rocha MR, Santos SD, Moura KR, Carvalho LS, Moura IH, Silva ARV. Health literacy and adherence to drug treatment of type 2 diabetes mellitus. Esc. Anna Nery. 2019;23(2):e20180325. doi: 10.1590/2177-9465-ean-2018-0325

21. Chehuen Neto JA, Costa LA, Estevanin GM, Bignoto TC, Vieira CIR, Pinto FAR, et al. Functional Health Literacy in chronic cardiovascular patients. Ciênc Saúde Colet. 2019;24(3):1121-32. doi: 10.1590/1413-81232018243.02212017

22. Paskulin LMG, Bierhals CCBK, Valer DB, Aires M, Guimarães NV, Brocker AR, et al. Health literacy of older people in primary care. Acta Paul Enferm. 2012;25(spe1):129-35. doi: 10.1590/S0103-21002012000800020

23. Silva PAB, Soares SM, Santos JFG, Silva LB. Cut-off point for WHOQOL-bref as a measure of quality of life of older adults. Rev Saúde Pública. 2014;48(3):390-7. doi: 10.1590/S0034-8910.2014048004912

24. Bezerra ASM, Lopes JLL, Barros ALBL. Adesão de pacientes hipertensos ao tratamento medicamentoso. Rev Bras Enferm. 2014;67(4):550-5. doi: 10.1590/0034-7167.2014670408

25. Universidade de São Paulo. Faculdade de Saúde Pública. Estudo Sabe, Saúde Bem-Estar e Envelhecimento, Condições de vida e saúde dos Idosos do Município de São Paulo [Internet]. 2015[cited 2015 Dec 21]. Available from: http://www.hygeia.fsp.usp.br/sabe

26. Lebrao ML, Laurenti R. Saúde, bem-estar e envelhecimento: o estudo SABE no Município de São Paulo. Rev Bras Epidemiol. 2005;8(2):127-41 doi: 10.1590/S1415-790X2005000200005

27. Suemoto CK, Ueda P, Beltrán-Sánchez H, Lebrão ML, Duarte YA, Wong R, et al. Development and Validation of a 10-Year Mortality Prediction Model: Meta-Analysis of Individual Participant Data From Five Cohorts of Older Adults in Developed and Developing Countries. J Gerontol A Biol Sci Med Sci. 2017;72(3):410-6. doi: 10.1093/gerona/glw166

28. Apolinario D, Lichtenthaler DG, Magaldi RM, Soares AT, Busse AL, Amaral JRG, et al. Using temporal orientation, category fluency, and word recall for detecting cognitive impairment: the 10-point cognitive screener (10-CS). Int J Geriatr Psychiatry. 2016;31(1):4-12. doi: 10.1002/ gps.4282

29. Malachias MVB, Souza WKSB, Plavnik FL, Rodrigues CIS, Brandão AA, Neves MFT, et al. 7a Diretriz Brasileira de Hipertensão Arterial. Arq Bras Cardiol [Internet]. 2016 [cited 2018 Jun 08];107(3Supl.3):1-83. Available from: http://publicacoes.cardiol.br/2014/diretrizes/2016/05_ HIPERTENSAO_ARTERIAL.pdf

30. Akpolat T, Erdem E, Aydogdu T. Validation of the Omron M3 Intellisense (HEM-7051-E) upper arm blood pressure monitor, for selfmeasurement, according to the European Society of Hypertension International Protocol revision 2010 in a stage 3-5 chronic kidney disease population. Kidney Blood Press Res. 2012;35(2):82-8. doi: 10.1159/000330719

31. Qaseem A, Wilt TJ, Rich R, Humphrey LL, Frost J, Forciea MA. Pharmacologic treatment of hypertension in adults aged 60 years or older to higher versus lower blood pressure targets: a clinical practice guideline from the American College of Physicians and the American Academy of Family Physicians. Ann Intern Med. 2017;166(6):430-7. doi: 10.7326/M16-1785 
32. Delgado $A B$, Lima ML. Contributo para a validação concorrente de uma medida de adesão aos tratamentos. Psicol. Saúde Doenças [Internet]. 2001 [cited 2019 Apr 15];2(2):81-100. Available from: http://www.scielo.mec.pt/scielo.php?script=sci_arttext\&pid $=$ S1645-00862001000200006

33. Strelec MAAM, Pierin AMG, Mion D Jr. The influence of patient's consciousness regarding high blood pressure and patient's attitude in face of disease controlling medicine intake. Arq Bras Cardiol. 2003;81(4):349-54. doi: 10.1590/S0066-782X2003001200002

34. Saliba D, Elliott M, Rubenstein LZ, Solomon DH, Young RT, Kamberg CJ, et al. The Vulnerable Elders Survey: a tool for identifying vulnerable older people in the community. J Am Geriatr Soc. 2001;49(12):1691-9. doi: 10.1046/j.1532-5415.2001.49281.x

35. Maia FOM, Duarte YAO, Secoli SR, Santos JLF, Lebrão ML. Cross-cultural adaptation of the Vulnerable Elders Survey-13 (VES-13): helping in the identification of vulnerable older people. Rev Esc Enferm USP. 2012;46(esp):116-22. doi: 10.1590/S0080-62342012000700017

36. Brooks C, Ballinger C, Nutbeam D, Mander C, Adams J. Nursing and allied health professionals' views about using health literacy screening tools and a universal precautions approach to communication with older adults: a qualitative study. Disabil Rehabil. 2019;22:1-7. doi: $10.1080 / 09638288.2018 .1538392$

37. Oliffe JL, McCreary DR, Black N, Flannigan R, Goldenberg SL. Canadian Men's Health Literacy: A Nationally Representative Study. Health Promot Pract. 2019:1524839919837625. doi: 10.1177/1524839919837625

38. Costa CM, Correa JGC. Os efeitos do alfabetismo funcional sobre a empregabilidade dos trabalhadores brasileiros. Rev Bras Estud Popul. 2014;31(1):7-27. doi: 10.1590/S0102-30982014000100002

39. Langan R, Jones K. Common questions about the initial management of hypertension. Am Fam Physician [Internet]. 2015 [cited 2019 Apr 15];91(3):172-7. Available from: https://www.aafp.org/afp/2015/0201/p172.html

40. Tavares DMS, Guimaraes MO, Ferreira PCS, Dias FA, Martins NPF, Rodrigues LR. Quality of life and accession to the pharmacological treatment among elderly hypertensive. Rev Bras Enferm [Internet]. 2016;69(1):122-9. doi: 10.1590/0034-7167.2016690118i

41. Kim J, Bushnell CD, Lee HS, Han SW. Effect of Adherence to Antihypertensive Medication on the Long-Term Outcome After Hemorrhagic Stroke in Korea. Hypertension. 2018;72(2):391-8. doi: 10.1161/HYPERTENSIONAHA.118.11139

42. Souza JG, Apolinario D, Magaldi RM, Busse AL, Campora F, Jacob-Filho W. Functional health literacy and glycaemic control in older adults with type 2 diabetes: A cross-sectional study. BMJ Open. 2014;4(2):e004180. doi: 10.1136/bmjopen-2013-004180

43. Silva SM, Santana ANC, Silva NNBD, Novaes MRCG. VES-13 and WHOQOL-bref cutoff points to detect quality of life in older adults in primary health care. Rev Saúde Pública. 2019;53:26. doi: 10.11606/s1518-8787.2019053000802

44. Marques SRL, Lemos SMA. Health literacy and associated factors in adults primary care users. Trab Educ Saúde. 2018;16(2):535-59. doi: 10.1590/1981-7746-sol00109 